\title{
Physical therapies in 19th century Aotearoa/New Zealand: Part 2 - Settler physical therapies
}

David A. Nicholls GradDip, MA, PhD, SFHEA

Associate Head (North), School of Public Health and Psychosocial Studies, Auckland University of Technology

Grayson Harwood BHSC (Physiotherapy), BSC (Anatomy and Structural Biology)

Physiotherapist, Cross Physiotherapy and Pilates, Wellington, New Zealand

\section{ABSTRACT}

This paper is the second of two reporting on a historiographic study of physical therapies in 19th century Aotearoa/New Zealand. This paper focuses on physical therapies practised by colonists, missionaries, pioneers, and other settlers to Aotearoa/New Zealand before 1900. The paper follows the methodological framework of the first paper and explores early medical development and some of the physical therapy practices of colonial settlers. We examine some of the living conditions experienced by colonial settlers and consider how 19th century ideologies contributed to a lack of formalised medical development in Aotearoa/New Zealand. We then explore the evidence of physical therapy practices and practitioners, who congregated mostly in the country's larger metropolitan centres, before concluding the paper with a discussion of some of the possible reasons for the distinct lack of physical therapies amongst the colonial settlers, when compared with the concurrent resurgence in physical therapy practices in Europe and North America.

\section{Nicholls D, Harwood G (2016) Physical therapies in 19th century Aotearoa/New Zealand: Part 2 - Settler physical therapies. New Zealand Journal of Physiotherapy 44(3): 124-132. doi: 10.15619/NZJP/44.3.02}

Key words: Masseur, Masseuse, Physical therapy, History, Aotearoa/New Zealand, Settler

\section{INTRODUCTION}

This paper reports on a study undertaken to examine why it appears that the physical therapies (massage and manipulation, electrotherapy, hydrotherapy and remedial exercise) were some of the most popular therapies in Europe and North America during the 19th century, but were almost completely absent from Aotearoa/New Zealand culture before 1900. In the paper, we detail the background to the study and outline a detailed historiographic account of existing texts, which show that there is some evidence of physical therapies being used by Māori prior to and during the 19th century. Subsequent papers will explore the practices of colonial settlers and argue that the particular nature of colonisation in New Zealand failed to create the conditions in which the physical therapies could flourish. We conclude these papers by arguing that although a few practitioners did establish themselves before 1900, accounts of their activities are incidental and piecemeal.

The origins of this study lie in five intersecting conditions. Firstly, physiotherapy in New Zealand celebrated its centenary in 2013, and the profession represents one manifestation of the physical therapies in an organised, disciplinary form. But this organisation only began in 1913, and in undertaking research into the profession's early history it appeared that there were few physical therapy practitioners in New Zealand prior to 1900. Secondly, a great deal of data exists indicating that the physical therapies were extremely popular and widely used in Europe and North America during the 19th century. And so thirdly, we assumed that many of the colonists who arrived in New Zealand from Australia, Europe and North America in the 19th century would have known about or been exposed to at least some of these therapies, and some may well have been practitioners themselves. Fourthly, we were aware that Māori used physical therapies as part of Indigenous healing practices, but that published accounts of massage and the use of thermal springs were limited. Finally, despite much of the development work taking place in the last two decades of the 19th century, the largest organised centre for the development of the physical therapies in New Zealand prior to 1913 - Rotorua Spa - did not become established until after 1901 with the creation of the world's first Department of Tourist and Health Resorts.

Given these five conditions, we asked what evidence existed for physical therapies in New Zealand; to what extent were they practised; by whom, where and when. The study used historiographic methods to identify and review texts from a wide range of primary and secondary sources, including published and unpublished manuscripts, period newspapers, personal accounts, photographs, registers and directories, available either online, through databases like Papers Past, or with first hand archival searching at Archives New Zealand, the Alexander Turnbull Library and the National Library. ${ }^{1}$ Secondary texts were also examined for accounts of physical therapies and evidence of interest in the subject. Before presenting the findings of the study, we will unpack some of the context underpinning the study and explain in more detail how the texts were identified and read.

\footnotetext{
All of the texts examined in this study were in the form of written documents. These inevitably privilege 'western' modes of historiographic recording. No primary oral accounts of Māori healing practices were identified, although some of these are reported by Pakeha in their own accounts of 19th century practices.
} 


\section{BACKGROUND}

This paper is the second to report on a study undertaken to examine why it appears that the physical therapies (massage and manipulation, electrotherapy, hydrotherapy and remedial exercise), were some of the most popular therapies in Europe and North America during the 19th century, but were almost completely absent from Aotearoa/New Zealand before 1900 . In the paper, we explore the lives of colonists, missionaries, pioneers, and other settlers during the 19th century, and examine the evidence for the existence of a small number of practising physical therapists from Australia, Europe and North America operating in larger population centres. We consider the living conditions of many of the settlers and speculate to what extent the atomisation and isolation of colonists limited the development of the physical therapies prior to 1900. We conclude the paper with a discussion of some of the reasons for the dearth of physical therapists and physical therapies in Aotearoa/New Zealand, with the exception of the Rotorua Spa, which is the focus for the third and final paper in the series.

To briefly recap, the rationale for this study lay in five intersecting conditions:

1. Knowledge of physiotherapy practices after 1913, but a sense that little existed before then;

2. The popularity of physical therapies in Europe and North America during the 19th century;

3. The assumption that many colonists would have known or practised physical therapies in their home country;

4. Evidence that Māori used physical therapies as part of indigenous healing practices;

5. The emergence of Rotorua Spa as a centre of organised physical therapy after 1901.

Given these five conditions, we asked what evidence existed for physical therapies in Aotearoa/New Zealand prior to the formation of the physiotherapy profession, World War I and the birth of the rehabilitation movement; and before state governments began to include physical therapy in organised formal health care services. We were interested to find out to what extent the physical therapies were practiced, by whom, where and when. To answer these questions, we analysed texts from a wide range of primary and secondary sources, including published and unpublished manuscripts, period newspapers, personal accounts, photographs, registers and directories, available either online, through published databases, or through first-hand archival searching. Secondary texts were also examined for accounts of physical therapies and evidence of interest in the subject.

In the previous paper titled Physical therapies in 19th century Aotearoa/New Zealand: Part 1 - Māori physical therapies, we showed that physical therapies were well known to Māori prior to colonisation. Unlike 'western' physical therapies, however, Māori practices were part of a holistic approach to treatment. Focusing on two 'orthopaedic' conditions (fractures and back pain) and two particular practices (massage and bathing), we argued that the physical therapies used by Māori bore many similarities to those practised by most cultures prior to colonisation, and that their results bore comparison with anything offered in the developing health care systems of the settlers who colonised Aotearoa/New Zealand after 1840.

Our focus now shifts to the settlers' experience, and the use they made of therapies that would have been well known to them in their home countries. To what extent were massage and manipulation, electrotherapy, hydrotherapy and remedial exercises practised and made available to ill and injured colonists? Where, and under what conditions, would a settler seek and receive physical therapies in Aotearoa/New Zealand prior to 1900? And were we correct to speculate that these therapies were underdeveloped and sparsely provided? If so, how might we make sense of this underdevelopment? We begin by considering a range of settler experiences, before exploring some of the practitioners who immigrated to Aotearoa/New Zealand in the second half of the 19th century.

\section{SETTLER EXPERIENCES}

In many ways, the colonisation of Aotearoa/New Zealand in the 19th century bore similarities to that of Australia and the United States. The Australian colonisation described by Charles Manning Clark, however, was one where many fraternal and 'mateship' ties developed as a necessary condition of bonding and indentured service (Clark and Cathcart 1993). Likewise, the rapid movement of settlers across America prior to 1900 was anchored to the development of population centres and the establishment of communities based on religious association (Turner 2008). With a few exceptions - the Presbyterian settlements in Otago, for instance - no such concentrated, collectivist colonisation occurred in Aotearoa/New Zealand. By contrast, the colonisation of Aotearoa/New Zealand was marked by a fierce individualism, atomisation and isolation (Fairburn 2013).

Aotearoa/New Zealand was aggressively marketed to people in Australia, England and North America as a new 'Arcadia'2 in which a working 'man' might escape the grinding poverty, grime and class-based prejudice of their homeland and achieve 'competence.' ${ }^{3}$ Werry describes the vision of a 'pastless, classless modernity against the background of a transcendent landscape by turns bucolic, primeval, and triumphantly sublime' (Werry 2011, p. xi). The simple idea that hard work would be enough for everyone to succeed was aggressively promoted by Edward Gibbon Wakefield's New Zealand Company and many others, who sought to take advantage of the country's abundant natural resources, space and temperate climate (Stuart 1971). Aotearoa/New Zealand was promoted as a worker's paradise that promised 'meat on every table, and... distance from the shadow of the workhouse door' (McLure 2004, p. 11). Furthermore, 'with nature's bounty so accessible [the settler]

\footnotetext{
2 Arcadia was a term used as a metaphor for an idyllic land - a pastoral paradise. Arcadia is, in reality, a mountainous district in southern Greece that was thought to be the mythical home of the Greek god Pan.

3 Achieving 'competence' was a term used to describe the ability to save enough money to buy one's own section of land and make a living from it.
} 
did not have to engage in collective enterprise to accumulate wealth' (Fairburn 2013, p. 56).

The reality, however, was somewhat different, with social isolation, weak community structures and unpredictable work patterns common for many. The atomisation experienced by many settlers was produced, in part, by the rapid expansion of colonists into Aotearoa/New Zealand's plentiful and sparsely populated bush, the itinerant nature of missionary work for many settlers, and unpredictable work patterns. Sixtytwo percent of the 165,000 working men registered in the 1881 census were in labouring classes, and their work was characterised by instability and frequent disruption. Farm work was mostly seasonal and vulnerable to poor harvests; manufacturing industry was small and uncompetitive when compared with imports, (and employers tended to employ boys and women to keep labour costs down); and building and construction moved through cycles of boom and bust, particularly during the Long Depression of the 1880s and 90s (Fairburn 2013).

It was labouring work, however, that was promoted most aggressively by community leaders who had already settled in the country, with some arguing that 'clerks and shopmen' would not rise in New Zealand, for the country's business houses were so small they employed few assistants' (Husthouse 1857). Various occupations were considered unwanted or oversupplied, including lawyers, clerks, tradesmen and office workers, bank clerks, and professional or trades people, and 'it was widely believed that people with particular vocations, a special expertise, a formal job training were ill adapted to the colony's needs' (Fairburn 2013, p. 54). This included health professionals.

Aotearoa/New Zealand's fierce individualism, unpredictable work patterns, and marginalisation of professional classes, had obvious implications for anyone wanting to practise the physical therapies, not least because of the slow growth and development of urban population centres. The national population in 1871 was reported as 267,000 people, spread over an area slightly more than 100,000 square miles (259,000 $\mathrm{km}^{2}$ ). Few institutions existed to facilitate mixing and meeting and few kinship ties developed. There were few centres for social engagement and civic development, and voluntary organisations struggled to develop a critical mass to sustain them. There was little leisure time for organised recreational activity, and much of the work (gum-digging, forestry, gold mining and shepherding, for example), was isolating. Loneliness was commonly found among the many transient workers too, who were required to move continually to find work. But it was not only working men that experienced the privations of social isolation and the difficulties of surviving in the country's bountiful but unforgiving bush. Elizabeth Colenso, wife of William Colenso, pioneering missionary with the Christian Missionary Society and friend to many of Aotearoa/New Zealand's preeminent settlers, lived for nine years at a remote rural station in Ahuriri, south of Napier on the North Island's east coast. While William spent much of his time travelling the country doing his missionary work, Elizabeth was left as a sole parent to two. Elizabeth overcame some of her feelings of isolation by acting as a community nurse $\mathrm{e}^{4}$ and schoolteacher. Elizabeth saw no other Pākehā woman for the first seven years at Ahuriri and visitors were rare. It is perhaps telling that when she received an offer to help with the delivery of her second daughter from a 'neighbour' in Turanga near Gisborne, she responded by walking the $200 \mathrm{~km}$ in mid-winter, eight months pregnant, with her 18 month-old daughter in tow.

Like Elizabeth Colenso's, the life of missionaries and colonial settlers was gruelling and hazardous, especially during the New Zealand Wars of the 1860s. As Ballantyne argues; 'Missionaries...routinely reflected on the physical consequences of the heavy labour, constant walking, and poor diet that accompanied missionary work... it seemed that death was never far from their door' (Ballantyne 2014, p. 7).

But the conditions for missionaries paled into insignificance in comparison with the lives led by the thousands of prospectors, or 'diggers' that entered the country after the discovery of gold in the 1850s;

Digging for gold was not healthy. A digger quickly wore out his young body, for he often lacked the clean water and good food that were his first needs if he was to keep well, and his work was hard and risky. A digging life not only weakened, sickened and wounded but could kill' (Eldred-Grigg, p.300).

Diggers were continually at risk of mortal illness and injury. They regularly fell down exposed mine shafts or were crushed under landslides or machinery. Worse still, living conditions for diggers were appalling with most suffering poor diets and physical exhaustion. Dysentery and typhoid were common and a complete lack of adequate sanitation created multiple vectors for the transmission of disease. Few men had family to fall back on, and there were numerous reports of '[s]ick men and boys [lying] helplessly in tents outside the town...for the digger who lacked cash to pay a hotel bill 'must rot' when he came down with typhoid' (Eldred-Grigg 2008, p. 303).

There was, therefore, no shortage of injury and illness that would have benefited from physical therapy, but formal and informal health services appear to have been severely limited, such that many men would have to risk their own livelihoods to help a fellow digger out of difficulty. Perhaps not surprisingly, the death toll among diggers during the 1860 gold rushes was heavier than that of the soldiers during the New Zealand Wars.

Part of the reason for the high morbidity and mortality rate in Aotearoa/New Zealand in the second half of the 19th century can be explained by the nature of the work undertaken by settlers, but Aotearoa/New Zealand was also a dangerous place for even the most cautious colonist. Numerous accounts exist of people stumbling into ngawha (boiling springs) in the middle of the night (see, for example, "About Volcanoes: Lecture by Mr. H. Hill, B.A," 1889, p. 2).

\footnotetext{
4 Much of the early nursing history of Aotearoa/New Zealand began with the wives of missionaries undertaking untrained nursing work in their communities (see, for example Maclean 1932).
} 
Many Victorian pioneers, settlers and travellers were enthralled by Aotearoa/New Zealand's untamed and uncultivated nature, but many were also unfamiliar with its flora and fauna, and there are many accounts of people simply starving to death while being surrounded by food that they had no knowledge how to process and consume. What made illness and injury so perilous though, was the relative absence of any formal medical services, a point of increasing concern among settlers as the century progressed, particularly in a country where death was so 'busy' (Eldred-Grigg 2008, p. 316).

\section{EARLY MEDICAL AND SOCIAL WELFARE DEVELOPMENT}

The early hospital system - such as it was - in Aotearoa/New Zealand was established prior to the New Zealand Wars and placed a big emphasis on the health of Māori. Hospitals in Auckland, New Plymouth and Wellington opened their doors in 1847, to be followed by Wanganui (1851) and Dunedin (1852), with subsidies provided by the British government (Dow 1995, p. 31). Māori use of the early hospitals went into decline after 1860 however, as a result of the New Zealand Wars, disruption of trade, and their susceptibility to introduced diseases. Many Māori chose to distance themselves from Pākehā medicine but many others also had their access restricted. As Claudia Orange has argued, 'settler interests obliterated almost all considerations of Māori welfare' (Orange 1994, p. 9).

The cultural shift in relations between Māori and Pākehā after 1860 had the indirect effect of creating more space for the growing dependent Pākehā population. ${ }^{5}$ After the initial midcentury hospital building programme, there was little further growth in organised health care, because there was little central funding or desire to coordinate care across the country, and most health care relied on a 'secondary and more discretionary system of charitable aid' (McClure 2013, p. 11). Many doctors operated in Aotearoa/New Zealand in the 19th century (Hocken 1909; Lawrenson n.d.), but few were subsidised or organised by central government, indeed there were only 15 subsidised doctors and dispensers employed by government in 1885, and only 30 by 1900 (Dow 1995, p. 32). Much changed after the 1891 election, however, with the Liberal Party instituting widespread social welfare programmes, including votes for women, old age pensions, factory reform and workplace arbitration (Hamer 1988).

Aotearoa/New Zealand remained a country of stark contrasts for much of the 19th century. While a few lived in relative comfort, spending their disposable income on servants, domestic luxuries and increasing leisure time, many toiled for long hours in poorly paid manual jobs:

Behind the sturdy, dignified facades of homes in tree-lined city streets, rough, draughty shanties were packed together three feet apart; rubbish filled the backyards, and the stench

\footnotetext{
The percentage of people over 65, for example, increased from $0.71 \%$ in 1861 to $1.42 \%$ in 1881 , and on to $4.05 \%$ in 1901 . This compares with a relatively stable elderly population in England, which changed from 4.64 to 4.66 percent during the same 40 year span (Fairburn 2013, p. 166).
}

overwhelmed health visitors who claimed the squalor in these quarters was as bad as that of old-world slums... Any mischance, a father's broken arm or a daughter's teenage pregnancy, could reduce poor families to extreme hardship and mean that a parent had to apply for charitable aid for relief (McClure 1998, 30).

Despite the promise of Arcadian splendor and abundant natural resources, many of the people of Aotearoa/New Zealand survived the 19th century rather than prospered, and the living conditions for many were bleak. The death rate in Dunedin from communicable diseases was comparable with heavily industrialised English towns like Manchester (Dow 1995, p. 20), and rates of injury from industry and conflict, the sequelae of communicable diseases, and the natural consequences of congenital disability and ageing, all contributed to a need for health care services. When one considers how many of these problems would have benefited from ongoing rehabilitation and physical therapy, it is hard to understand how few physical therapists actually operated in Aotearoa/New Zealand prior to 1900. What evidence do we have, therefore, of physical therapies and physical therapists operating in Aotearoa/New Zealand in the 19th century?

\section{PHYSICAL THERAPISTS}

Despite the growing influence of pioneers and settlers from Europe and North America during the 19th century, few masseurs, medical electricians, hydrotherapists, balneologists or medical gymnasts appear in the archives before 1880. A search of the Papers Past archive (http://paperspast.natlib.govt.nz/ cgi-bin/paperspast) for news media from the time for masseurs and masseuses shows only two results, and both of these are erroneous. From 1880 onwards, sporadic accounts of massage practices from around the colonies are interspersed with small items of local news. The Mount Ida Chronicle from November 1888, for example, mentions a masseuse who has administered massage to only one woman in her years of practice whose ribs have not been displaced due to corset wearing ("Local and General," 1888), while the Southland Times describes an 'An Old Fad Revived' in promoting massage as a job opportunity particularly suited to women (Southland Times, 1887). In the same year, the New Zealand Herald reprinted excerpts of Wilkie Collins' book The Legacy of Cain, which includes a masseuse as one of its main characters ("The Legacy of Cain," 1888), and reports that a masseur was put into a lunatic asylum in Paris ("Personal Notes," 1888). Beyond this there is little evidence of any significant interest or involvement of masseurs and masseuses in Aotearoa/New Zealand life.

Louise Shaw, in her recent history of the School of Physiotherapy in Otago has identified that;

[m]asseurs were not specifically identified in the Aotearoa/New Zealand census until 1901 and, even then, only 20 men and 38 women were recorded including 12 medical electricians and their assistants. It was not until the First World War that the number of massage practitioners increased dramatically; the 1916 census recorded 65 masseurs and 93 masseuses (Shaw 2013, p. 21). 
Despite this, we know of a handful of practitioners who plied their trade in Aotearoa/New Zealand before 1900. Most were masseurs or medical electricians, some were masseuses, and some were physicians incorporating massage and electrotherapy from their practices. With few exceptions, most operated in the major population centres. What are largely invisible in the archives are accounts of the women missionaries, overseastrained nurses, and other women pioneers and settlers who acted as community nurses, and may have practised some form of rudimentary physical therapy as part of their healing practice. Wilson, for example, argues that;

[u]ntil the enactment of the Medical Practitioners Act of 1868, [and] the introduction of compulsory registration for doctors, there was considerable overlap between the roles of the various health care providers in New Zealand. Midwives, nurses and chemists often prescribed for and treated patients, and doctors occasionally provided 24 hour nursing care for wealthy patients (Wilson 1998, p. 15).

Similarly, accounts of Māori physical therapies almost disappear from the archives after the New Zealand Wars of the 1860s, perhaps pointing to the declining fortunes of Māori in general in the latter half of the 19th century.

The only non-metropolitan locations that serve as a focal point for physical therapy practices in Aotearoa/New Zealand before 1900 are the spa centres at Hanmer Springs, Te Aroha, Waiwera and, most significantly, Rotorua. After the Te Arawa tribe agreed to give up its land and become lease-holders over Rotorua's thermal springs region in 1880, the government acted quickly to cede control over all of the valuable thermal springs, passing the Thermal-Springs District Act in 1881 'to codify the process it had already begun in Rotorua, legislating on the principle of reserving thermal districts for the use of the nation' (McLure 2004 , p. 14). Because of the significance of Rotorua to the history of physical therapy in Aotearoa/New Zealand, we will address it as a separate paper. Of the remaining practitioners, we have divided them into three groups: government appointees, maverick practitioners and others. This is somewhat arbitrary, however, since most practitioners needed to operate across a number of clinical spaces in order to make a living.

\section{Government appointees}

Honorary (meaning unpaid) hospital appointments were some of the few formal medical appointments made prior to 1890. In 1887, for example, Christchurch Hospital appointed Harcourt Gardner, ex-lecturer in electricity at Royal Polytechnic Institute in London, as 'Honorary Galvanist' in a part time role. Gardner's role was to treat the male patients with the galvanic battery, while his wife treated women outside hospital appointment times. Shaw reports that they treated such conditions as 'rheumatism, lumbago, neuralgia, spinal weakness, liver complaints and nervous exhaustion' (Shaw 2013, pp. 15-16). Six years later, the same hospital appointed another English migrant - Charles Mackinlay Hilson - to succeed Gardner (Bennett 1962). Hilson was an ex-medical student and had no formal medical qualifications, yet he treated sprains, nervous diseases and cases of paralysis when referred (Shaw 2013, p. 17). Interestingly, when Hilson resigned in 1895, after just two years in the post, it was 12 years before the hospital re-appointed to the position, suggesting that the post was not considered a high priority.

Honorary appointments were valuable because they provided legitimacy at a time before formal professional registration and regulation of health professions. They may have also been a source of private paying patients who could be seen in the practitioner's own rooms. Hilson, like his counterparts, ran his own private practice. Advertisements in the local paper - The Press - show that;

Mr Hilson, masseur, has commenced the practice of his profession in this city. Messages or letters may be left at Bennington's Chemist; address care Mrs Rawson, 177 Worcester Street ("Advertisements," 1893).

Adverts from 1893 indicate that Hilson saw patients between quite limited hours (2-3pm and 6-7pm). Later in 1894, Hilson was advertising that he was available 'At home' from 9-10am and from 7-7:30pm ("Advertisements," 1894), suggesting that the work available at the time was insufficient to maintain a significant practice in massage and medical electricity alone.

One way that practitioners attempted to promote their practice was through the publication of testimonials from patients who had been treated successfully. In 1893, for example, The Press published this review of Hilson's work from a patient;

I was paralysed for about four years, and had lost all control over the lower limbs of my body, being so helpless as to have to be carried to my bed in the Hospital [sic], but after less than three weeks under the massage treatment of Mr. C. Mackinley Hilson, the Honorary Masseur to our local Hospital, I am now able to walk with [sic] any assistance whatever ("Public Thanks to Our Hospital," 1893).

Hilson, however, left Aotearoa/New Zealand in 1895, entering into private practice in Hobart, Tasmania. One year later, Wellington Hospital appointed its own Honorary Masseur - A. A. Howes. Like Hilson, Howes was obliged to consult privately as well as undertake work at the hospital. The Evening Post advertised that 'Messages may be left [for Howes] and consultations arranged for, at Giesen's Pharmacy, Willis-street [sic]. Telephone No. 644' (Evening Post, 1896).

Two of the more significant figures in physical therapy before 1900 were Herman Roth and his brother Gustave. Herman arrived in New Zealand in August 1893 as the first masseur formally appointed to the Government Sanatorium and Baths in Rotorua. ${ }^{6}$ Roth established himself in Rotorua throughout each summer, in Auckland in May and June, and in Wellington for the rest of the year (New Zealand Herald, 1895). While in Wellington, Roth published a small brochure, entitled Massage; Its History and Therapeutics. In it he states that 'he has made arrangements for the erection of a private hospital at Rotorua, suitable for the accommodation and special treatment of invalids, where assistants—-both male and female—will be in

\footnotetext{
6 Herman Roth's work at the Rotorua Spa will be featured in more detail in the subsequent paper.
} 
attendance, and a masseuse for ladies' (New Zealand Herald, 1895)

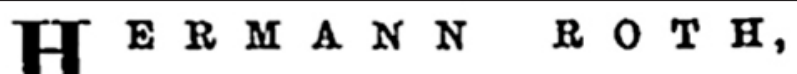 MASSAGE SPECIALIST, Appointed to 8 Sanatorinm and tho Government

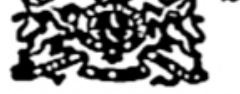 Baths, \\ CAN BE CONSULTED FREE}

From 11 until 1 o'olock any day at Phœnix Chambers, Lambton-quay.

\section{Peipltx Addrk88-Occidental Hotre. MASSEUSE FOR LADIES.}

Mr. Rotr's book on "Massage," \&o., can be bad at any Chomist's gratis.

Bheumatiom, gout, lumbago, soiatioa, hysteria, epinal diseases, nenralgiв, dyвpopsis, fatulence, constipation, insomnia, sprains, all nervous and joint diseases, aro not only relieved but permanently ourod. Mrasege not only treats the effeots, but removes the couse.

Mr. Roth has had a very wide experience in Gormany, America, England, and Scots land; be bas been attending Hospitals in addition to private practice, and bad opportunities of working with the best Surgeons and Physioiens of the rorld.

His testimonials and credentials are of the very highest.

University of Glaegow, July, 1892.

Mr. Roth was known to mo during his residence in Glasgow from bis having treated various pationts of mine, both in privato praotice and in my clinical wards in the Hospital. From whst I Baw of his work, I sm satisfied that he thoroughly understands his profession, and is an admirablo Mresseur. I have mach plessure in recommending $\mathbf{M r}$. Roth as being, so far as I have been able to judge, an efficient and reliablo operator. (Signed) Gro. McLrod,

Knight, M.D., LL.D., Regius Professor of Surgery University of Glasgor, and Sur. geon in Ordinary to the Queon in Scot. land.

Figure 1. Advertisement for Herman Roth

Like many of his contemporaries, Roth was not averse to making bold claims that he could not only 'relieve' but 'cure' conditions such as 'Rheumatism, Gout, Lumbago, Sciatica, Paralysis, Hysteria, Spinal diseases. Neuralgia, Dyspepsia, Flatulence, Constipation, Sprains, Insomnia, all nervous and joint Diseases' ("Advertisement," 1895). Roth traded on his 'very wide experience in Germany, America, England, Scotland, and the
Colonies' and the work that he done with 'the best Surgeons and Physicians of the world' ("Advertisement," 1895). Roth consulted in his rooms for limited hours each day, and charged 5 s to 7 s $6 d$ (equivalent to $\$ N Z 45-70)^{7}$ for each consultation. Roth continued to be listed in the Post Office Directory as one of the few masseurs practising in Auckland in 1898-9. Roth's brother Gustave, however, was never listed as a massage practitioner.

\section{Maverick practitioners}

If Herman Roth presents the image of a professional practitioner developing a sober clinical practice in a new colony, his brother offers a different picture. Gustave Roth took over Herman's practice in 1898, and in the space of a few months had been convicted of stealing and then pawning a bicycle in Auckland ("A Masseur in Court," 1898), becoming a 'great favourite with the ladies' in Rotorua ("On the Bike: A Trip to Rotorua (by a Cyclist)," 1897), and becoming embroiled in a court case involving the spurious use of electrotherapy for the treatment of cancer, by an equally disreputable 'medical electrician and cancer specialist,' William Stanton ("Inquest on Mrs Hayden," 1899).

Roth's exuberance was perhaps emblematic of a class of practitioner that drew on the perceived power of medical electricity and massage to animate the torpid body: to galvanise and mesmerise, and restore the ailing body to health. Histories of late-Victorian medicine in Europe and North America are replete with accounts of charlatans, conmen and snake-oil salesmen, so we should not be surprised to find such characters appearing in New Zealand, particularly given the laissez-faire approach to practice regulation that existed before 1900 .

'Professor' J.B. Thomas, 'Specialist in Medical Electricity, Massage and [the] Swedish movement Cure' professional phrenologist and physiognomist was one such practitioner. Between 1887 and 1893, Thomas visited Aotearoa/New Zealand, giving public lectures, character readings and electrotherapy demonstrations that offered 'entertainment interesting to all classes, to all ages, and to people of every standard of intelligence' (Tuapeka Times, 1893).

Thomas followed a trend after the 1880s for a few well-known galvanists like George Milner Stephen and 'Professor Richard, ME (medical electrician)' to visit New Zealand and offer public lectures and demonstrations of electrotherapy in local theatres (Broadley 2000). More interesting, perhaps, were the medical electricians that established their practices in the main centres after 1880. John Jenkins set up a 'Magnetic and Galvanic Healing Institute' in Rattray Street, Dunedin in 1883. Jenkins was interested in 'psychic potencies' of electrotherapy - unblocking flows of internal energy and revitalising patients (Shaw 2013, p. 18). His practice was so popular that 'by 1895 , he had not only extended and renovated his premises, but had also installed his own generator and electric light fittings, long before there were municipal facilities' (2013, p. 18). 'Part scientist, part showman,

Based on http://www.rbnz.govt.nz/monetary_policy/inflation_ calculator/ 
Jenkins created a lifelike female automaton that glided about, turning her head and moving her eyes...'Electra' [lived in] an adjacent anteroom to his professional rooms, much to the delight of his clients' (2013, p. 18).

Perhaps the most well-known physical therapist in New Zealand before 1900 was, however, the Scottish blacksmith, animal 'doctor,' masseur, hairdresser and dentist, Matthew Guinan. Guinan was the first of four generations of practitioners in the South Island of Aotearoa/New Zealand to become physiotherapists. ${ }^{8}$ Louise Shaw describes how he possessed the kinds of initiative, adaptability and skills that were 'necessary prerequisites for economic survival in the colonies' (2013, p. 18). Guinan arrived in Dunedin in 1875, aged 19, and settled in Kelso, a small settlement in Otago that was established in the year of his arrival. Here he worked as a blacksmith and horse 'doctor,' and began to gain a reputation for his 'magnetic touch' (Brownlie 1992). One of his medical innovations included the production of liniments and lotions that he sold from rooms that became known as 'Matt's Hospital.' Brownlie suggests that in the 1880s and 90s, people travelled from all over the country to visit him, filling up guest houses with 'invalids' (1992). Guinan became so successful that he was able to relocate to a practice in George Street, Dunedin in 1916 (Nicholls 2009). ${ }^{9}$

\section{Other masseurs}

It is likely that a number of other physical therapists operated throughout New Zealand prior to 1900, and some would only have been known locally. Some, like German-trained Margaret Culling, were operating in Rotorua in the 1890s alongside Alfred Grinders, Camille Malfroy and Arthur Wohlmann, who helped to establish the Rotorua Spa. ${ }^{10}$ New Yorker D. Edwin Booth and his English wife Mary ran a successful practice in Dunedin in the last decade of the nineteenth century (Shaw 2013), while the trend for promoting massage by blind men and women extended to New Zealand, where Miss Annie Chamberlain was trained as a masseuse by 'a medical man' with the support of the Charity Organisation Society.

For most of these practitioners, the only way to obtain reliable work was through advertisements in the popular newspapers, medical referral and word-of-mouth. Some practitioners imported small appliances that were popular therapeutic novelties overseas. Dr. Forest's muscle roller, which was advertised in the Timaru Herald in 1892, claimed to cure 'The tired muscles or sprains, etc., of [the] footballer, as well as headaches, neuralgia, dyspepsia, constipation' ("Health, the New Method [Adv.]," 1892).

Notwithstanding these few cases, however, numbers of physical therapists in New Zealand prior to 1900 remained small. The

\footnotetext{
8 Taxonomically speaking, Guinan was not, himself, a physiotherapist, since his practice ended before physiotherapy became a registered profession in 1921.

9 An oral history interview discussing Matthew Guinan's legacy by his great grandson - Frank Weedon, who was himself a physiotherapist and lecturer at the School of Physiotherapy in Otago - can be heard here: http://www.100yearsofphysio.co.nz/oral-histories/frankweedon/\#.Vh_qJLRde38.

10 These will be discussed in more detail in the final paper in this series.
}

Post Office directory of businesses lists only 11 registered masseurs in New Zealand in 1899: Miss Christina Cottman, P. M. Dewar, Miss McElwain, Herman Roth and William Stanton in Auckland; Miss A. Craig in Palmerston North; Miss Wildman in Wellington; A. E. Howes, Thomas B. Pike, and George Weston in Christchurch; and Miss Margaret O. Culling in Dunedin. There were a further four 'medical galvanists,' and 14 purveyors of private baths and hot springs located in the main regional centres or spa sites. The 1896 census reported that there were 703,000 non-Māori and 40,000 Māori residing in New Zealand, so if we take a generous view and call each of these purveyors and providers 'physical therapists' and assume that there were at least twice as many un-registered masseurs and masseuses practising within New Zealand at the end of the century, it would still equate to only one masseur or masseuse for every 7,500 people, or one therapist for every 1,000 square miles $\left(2,590 \mathrm{~km}^{2}\right) .{ }^{11}$

\section{DISCUSSION}

The evidence presented here suggests the experience of physical therapy in the 19th century was somewhat different for colonists, pioneers and settlers than it had been for Māori. Where Māori practised physical therapies without a commercial imperative, making use of natural resources like hot springs and Aotearoa/New Zealand's abundant flora, Pākehā appear to have seen massage, electrotherapy, hydrotherapy and remedial gymnastics as exotic luxuries, only available in the metropolitan areas and dedicated therapeutic sites. The physical therapies were available to those who had surplus time and money and were not freely available to the vast majority of the population who had not achieved a 'competence' and eked out subsistence wages sufficient only to feed and house themselves and their growing families. Without organised health and welfare services prior to 1900, there were few opportunities for working people to enjoy private physical therapies.

Given that we know that many colonists acted as makeshift midwives, nurses and even surgeons in the agricultural settlements, gold fields and remote bush communities that were dotted throughout the country, it is likely that many also served as physical therapists, providing therapeutic massage and remedial exercises to help people recover from illness and injury. But data is sparse here and we are dependent on inference drawn from personal biographies, secondary accounts, and narrative histories, which all suffer, to varying degrees, from being romanticised accounts of events.

As much as there were differences in the way Māori and Pākehā practised the physical therapies, we also know that there were some similarities. Māori saw the physical therapies as intertwined with spiritual and herbal practices in the same

\footnotetext{
11 Some detailed accounts of Auckland's Turkish Baths, 'health suppliers' who provided physical therapy services, along with the biographies of an assortment of hygienic face masseuses, manicurists, hypnotists, hydropathists, convalescent home proprietors, doctors of magnetism and magnetic healers can be found in the 1902 Cyclopedia of New Zealand (http://nzetc.victoria.ac.nz/tm/scholarly/ tei-corpus-cyclopedia.html).
} 
way that Pākehā therapists combined the physical therapies with pharmacy and surgery. Prior to 1900, 'orthodox' medical practice had not been heavily inflected with 'germ theory' in New Zealand, and most medical practitioners were trained in the physical therapies (see, for example Ottosson 2011, 2015). Equally, Māori saw therapeutic practices as the province of a tohunga, in the same way that Pākehā believed that medical practitioners should be well trained and, ultimately, registered. Registration for physiotherapists would not, however, come into effect until 1921 in New Zealand, by which time physical therapy practices had received a boost from four related events: the Liberal government's investment in organised health and welfare services for the entire population; the development of the four main spa centres, most notably the Rotorua Spa; the successful registration of masseuses (before even midwives and nurses) in England in 1895; and the outbreak of World War I, which necessitated the deployment of masseuses to front-line medical care and the development of physical rehabilitation services for returning soldiers.

The most significant of these events for physical therapies in the 19th century was the development of the Rotorua Spa which, although not completed until 1908, followed more than 25 years of effort and investment, and an ongoing discussion about the economic and health benefits of physical therapies to people living in Aotearoa/New Zealand, and to those overseas. The development of the Spa, and its associated discourses, will be explored in the next paper.

\section{CONCLUSION}

In this paper we have focused on the settler experience and the effect that colonisation had on physical therapy practices before 1900. The particular cultural value Pākehā placed on independence and autonomy, and the possibilities that settlers could rid themselves of the privations of their homeland, led many into lifestyles that were physically demanding, isolated and hazardous. Despite this, few formal health care services were established, and an attitude of self-reliance accompanied a fierce independence.

As Māori cultural practices were slowly 'cleansed' by engineered conflicts, progressive economic reforms and colonial legislation, a vacuum was created in which Pākehā health practices could emerge. Lacking any formal infrastructure, however, physical therapies remained either the province of maverick practitioners, or luxurious indulgences of those with the surplus time and money. Physical therapies as we would come to know them in the early part of the 20th century would therefore be confined to a handful of practitioners in the four main metropolitan centres. The exceptions to this were the four spa centres at Hanmer Springs, Rotorua, Te Aroha and Waiwera, and the largest of these - Rotorua - became 'a haven for the colony's emerging Pākehā professional managerial class' and the wealthy invalid from overseas (Werry 2011, p. 22). It is to this celebration of the benefits of the physical therapies, consolidated in the complex interwoven discourses surrounding the Rotorua Spa that we turn in the third and final paper in this series.

\section{KEY POINTS}

1. Despite their popularity in Europe and North America, there is little evidence of the use of physical therapies by New Zealand settlers before 1900

2. Most physical therapies were confined to the larger metropolitan centres and were often eclectic and eccentric in their approach

3. People living in remote and rural locations had very poor access to health services and evidence suggests that their health suffered greatly as a result.

\section{DISCLOSURES}

This study was supported by an Auckland University of Technology Faculty of Health and Environmental Sciences Summer Research Award (CGHS 10/14).

\section{ADDRESS FOR CORRESPONDENCE}

Associate Professor David A. Nicholls, A-11, School of Clinical Sciences, Faculty of Health and Environmental Sciences, Auckland University of Technology, Private Bag 92006, Auckland 0627, New Zealand. Email: david.nicholls@aut.ac.nz. Telephone: $099219999 \times 7064$

\section{REFERENCES}

About Volcanoes: Lecture by Mr. H. Hill, B.A (1889, September 5) Bush Advocate.

Advertisements (1895, July 19) Evening Post, p. 4.

Advertisements (1893, August 12) The Press, p. 1.

Advertisements (1894, October 17) The Press, p. 1.

Angus J (1984) A history of the Otago Hospital Board and its predecessors. Dunedin: Otago Hospital Board.

Ballantyne T (2014) Entanglements of empire: Missionaries, Ma $\square$ ori, and the question of the body. Durham: Duke University Press.

Bennett FO (1962) Hospital on the Avon: The history of the Christchurch Hospital, 1862-1962. Christchurch: North Canterbury Hospital Board.

Broadley SD (2000) Spirited visions: A study of spiritualism in New Zealand settler society, 1870-90. PhD, University of Otago, Dunedin, New Zealand.

Brownlie M (1992) Kismet for Kelso. Gore: Gore Publishing.

Clark CMH and Cathcart M (1993) Manning Clark's history of Australia. Carlton, Victoria: Melbourne University Press.

Dow DA (1995) Safeguarding the public health: A history of the New Zealand Department of Health. Wellington: Victoria University Press.

Dr Duncan MacGregor's Report on the Government Sanatorium (1896, August 5) Hot Lakes Chronicle, p. 2.

Eldred-Grigg S (2008) Diggers, hatters, and whores: The story of the New Zealand gold rushes. Auckland, N.Z.: Random House.

Fairburn M (2013) The ideal society and its enemies: Foundations of modern New Zealand society, 1850-1900. New York: Auckland University Press.

Hamer DA (1988) The New Zealand liberals: The years of power, 1891-1912. Auckland: Auckland University Press.

Health, the New Method [Adv.] (1892, September 28) Timaru Herald, p. 2

Hocken TM (1909) A bibliography of the literature relating to New Zealand. Wellington: John Mackay. 
Husthouse C (1857) New Zealand, the 'Britain of the south': With a chapter on the native war, and our future native policy. London: Edward Stanford.

Inquest on Mrs Hayden (1899, May 16) Auckland Star, p. 2.

Lawrenson R (n.d.) Medical practice in New Zealand 1769-1860.

The Legacy of Cain (1888, June 6) New Zealand Herald.

Local and General_(1888, November 1) Mount Ida Chronicle.

Maclean H (1932) Nursing in New Zealand. Wellington: Tolan.

A Masseur in Court (1898, November 21) Auckland Star, p. 5.

McClure M (2013) A civilised community - a history of social security in New Zealand 1898-1998. New York: Auckland University Press.

McLure M (2004) The wonder country: Making New Zealand tourism. Auckland: Auckland University Press.

Nicholls DA (2009) Making history - the "grandfather" of physiotherapy in New Zealand. PhysioMatters, 20-1.

The Editor. (1893, May 3). Notices. Tuapeka Times, p. 2.

The Editor. (1895, January 1). Notices. New Zealand Herald, p. 5.

The Editor. (1896, June 20). Notices. Evening Post, p. 7.

The Editor. (1887, November 30). An Old Fad Revived. Southland Times.

Olssen E and Stenson M (1989) A century of change: New Zealand, 18001900. Auckland, N.Z.: Longman Paul.

On the Bike: A Trip to Rotorua (by a Cyclist) (1897, January 16) Auckland Star, p. 4

Orange C (1994) The turbulent years: The Māori biographies from the dictionary of New Zealand biography, volume 2, 1870-1900. Wellington, N.Z.: Bridget Williams Books.
Ottosson A (2011) The manipulated history of manipulations of spines and joints? Rethinking orthopaedic medicine through the 19th century discourse of European mechanical medicine. Medicine Studies, 3(2), 83116. doi:10.1007/s12376-011-0067-3.

Ottosson A (2015) One history or many herstories? Gender politics and the history of physiotherapy's origins in the nineteenth and early twentieth century. Women's History Review. doi:10.1080/09612025.2015.1071581.

Personal Notes (1888, September 1) New Zealand Herald.

Public Thanks to Our Hospital (1893, September 16) The Press, p. 5.

Shaw L (2013) In our hands: 100 years of the School of Physiotherapy in Otago 1913-2013. Dunedin: University of Otago.

Smillie A (2003) The end of tranquillity? An exploration of some organisational and societal factors that generated discord upon the introduction of trained nurses into New Zealand hospitals, 1885-1914. Master of Arts, Victoria University, Wellington, New Zealand.

Stuart PA (1971) Edward Gibbon Wakefield in New Zealand: His political career, 1853-4. Victoria University Press.

Turner FJ (2008) The significance of the frontier in American history. London: Penguin.

Werry M (2011) The tourist state: Performing leisure, liberalism, and race in New Zealand. Minneapolis: University of Minnesota Press.

Wilson KF (1998) Angels in the devil's pit: Nursing in Rotorua, 1840-1940. Karo Press. 